\title{
Photoabsorption effect in the thin films of the CdPbS solid solutions
}

\author{
C Vyacheslav F. Markov, ${ }^{1,2 *}$ Karina V. Grashchenkova, ${ }^{1}$ Larisa N. Maskaeva, ${ }^{1,2+}$ \\ Yury G. Shashmurin, ${ }^{1}$ and Anastasia D. Kutyavina ${ }^{1}$ \\ ${ }^{1}$ Physical and Colloidal Chemistry Department. Ural Federal University Named After the First President \\ of Russia B.N. Yeltsin. Mira St., 19. Yekaterinburg, 620002. Sverdlovsk Region. Russia. \\ Phone: +7 (343) 375-93-18. E-mail:mln@ural.ru \\ ${ }^{2}$ Ural State Fire Service Institute of Emergency Ministry of Russia. Mira St., 22. Yekaterinburg, 620022. \\ Sverdlovsk Region. Russia. Phone: +7 (343) 360-81-68.
}

\begin{abstract}
Keywords: photoabsorption effect, thin films, solid solutions in the PbS-CdS system,
\end{abstract} chemical bath deposition, chemical sensors, nitrogen dioxide.

\section{Abstract}

In this work, we have attempted to detect the photoadsorption effect using various photoactivation sources of semiconductor layers of $\mathrm{Cd}_{x} \mathrm{~Pb}_{1-x} \mathrm{~S}$ solid solutions that are sensitive to the presence of nitrogen dioxide in air. For this purpose, $\mathrm{Cd}_{x} \mathrm{~Pb}_{1-x} \mathrm{~S}$ films (up to $600 \mathrm{~nm}$ thick) were synthesized from the citrate ammonia reaction system by the chemical bath deposition (CBD) on glass and sitall substrates. Using XRD analysis, we determined the structure and composition of $\mathrm{Cd}_{x} \mathrm{~Pb}_{1-x} \mathrm{~S}$ solid solutions. It was found that all films crystallize in the cubic structure $B 1$ of lead sulfide. Taking into account the content of the substituting component in the samples and comparing it with the equilibrium phase diagrams of the PbS-CdS system, we concluded that the obtained solid solutions are strongly supersaturated in nature. The cadmium content in the $\mathrm{PbS}$ lattice increases in films deposited on sitall and glass from 3.9 to 5.9 and from 4.3 to 5.4 at.\% with an increase in the deposition time from 60 to 120 minutes, respectively. It must be noted that their crystallinity degree increases with increasing deposition time. The size of the particles forming the layers was determined by SEM microscopy. The predominant crystallite diameter is $250-300 \mathrm{~nm}$. The sensory properties of films of $\mathrm{Cd}_{x} \mathrm{~Pb}_{1-x} \mathrm{~S}$ solid solutions with respect to the presence of nitrogen dioxide with a concentration of $100 \mathrm{mg} / \mathrm{m}^{3}$ in air were studied using preliminary photoactivation by various sources with a radiation wavelength from 420 to $1000 \mathrm{~nm}$. For the first time, a positive photoadsorption effect was revealed for CBD produced films of $\mathrm{Cd}_{x} \mathrm{~Pb}_{1-x} \mathrm{~S}$ solid solutions. The preliminary photoactivation of the films with a blue lamp (760-1000 $\left.\mathrm{nm}\right)$ for 9-13 minutes allows the film to increase the response to $\mathrm{NO}_{2}$ more than doubled. A high relaxation rate of $\mathrm{Cd}_{x} \mathrm{~Pb}_{1-x} \mathrm{~S}$-based sensor elements after contact with nitrogen dioxide was shown to be 4-10 minutes, which allows to reuse it.

\section{References}

[1] V.G. Baru, F.F. Volkenstein. The effect of irradiation on the surface properties of semiconductors. Moscow: Nauka. 1978. 288p. (russian)

[2] F.F. Volkenstein, I.V. Karpenko. On the sign of the photodesorption effect on semiconductors with the exciton mechanism of light absorption. Physics of the Solid State. 1967. Vol.9. No.2. P.403-410. (russian)

[3] V.N. Kuznetsov, A.A. Lisachenko, T.K. Skaletskaya. The effect of ultraviolet radiation on the adsorption and catalytic properties of BeO. Russian J. of Phys. Chem. 1980. Vol.54. No. 10. P.2596-2600. (russian)

[4] V.N. Kuznetsov, A.A. Lisachenko, T.K. Skaletskaya. Adsorption and disproportionation of nitric oxide on UV irradiated $\mathrm{Al}_{2} \mathrm{O}_{3}$. Kinetics and catalysis. 1983. Vol.24. No.6. P.1442-1447. (russian)

[5] V.N. Kuznetsov, A.A. Lisachenko, T.K. Skaletskaya. Photoactivated reactions of oxygen and nitrogen oxides to $\mathrm{BeO}$ and their spectral manifestations. Kinetics and catalysis. 1985. Vol.24. No.2. P.368-372. (russian)

[6] Yu.M. Artemyev, E.A. Balakireva. Photoadsorption of oxygen and hydrogen on tantalum(V) oxide modified with iron-oxygen groups. Bulletin of St. Petersburg State University. 2006. Iss.4. No.4. P.102106. (russian)

[7] Y. Takahara, J.N. Kondo, D. Lu, K. Domen. Synthesis and application for overall water splitting of transition metal-mixed mesoporous Ta oxide. Solid State Ionics. 2002. Vol.151. Iss.1-4. P.305-311. DOI: $10.1016 / \mathrm{S} 0167-2738(02) 00728-2$ 
[8] H. Kato, A. Kudo. Energy structure and photocatalytic activity for water splitting of $\operatorname{Sr}_{2}\left(\mathrm{Ta}_{1-X} \mathrm{Nb}_{X}\right)_{2} \mathrm{O}_{7}$ solid solution. J. Photochem. Photobiol. A: Chem. 2001. Vol.145. Iss.1-2. P.129-133. DOI: 10.1016/S1010-6030(01)00574-3

[9] M. Hara, G. Hitoki, T. Takata, J.N. Kondo, H. Kobayashi, K. Domenac. TaON and $\mathrm{Ta}_{3} \mathrm{~N}_{5}$ as new visible light driven photocatalysts. Catalysis Today. 2003. Vol.78. Iss.1-4. P.555-560. DOI: 10.1016/S09205861(02)00354-1

[10] V.N. Parmon, V.S. Zakharenko. Photocatalysis and photosorption in the earth's atmosphere. Chemistry for sustainable development. 2001. No.9. P.461-483. (russian)

[11] V.S. Zakharenko, V.N. Parmon, K.I. Zamaraev. Photoadsorption and photocatalytic processes affecting the composition of the Earth's atmosphere. I. Irreversible photo-adsorption of Freon-134 on magnesium oxide under conditions close to atmospheric. Kinetics and catalysis. 1997. Vol.38. No.1. P.140-144. (russian)

[12] V.S. Zakharenko, V.N. Parmon. Composition of the adsorbed layer on the surface of magnesia in the presence of atmospheric air. Russian Journal of Physical Chemistry. 1999. Vol.73. No.1. P.117-120.

[13] V.S. Zakharenko, V.N. Parmon. Remediation of the Earth's atmosphere through photoinitiated destruction of freons on the alkaline earth oxide components of tropospheric aerosols. Colloids and Surfaces. Ser.A: Physicochemical and Engineering Aspects. 1999. Vol.151. No.1-2. P.367-376. DOI: 10.1016/S0927-7757(98)00699-2

[14] Kwan. T. Electronic phenomena in chemisorption and catalysis on semiconductors (K. Hauffe and Th. Wolkenstein, eds.). Berlin: De Gruyter. 1969. P.184.

[15] F.S. Stone. Coloquio sobre quimica fisica de processes on superjicies solides. Madrid. 1965. P.109.

[16] R.I. Bickley, R.K.M. Jayanty. Faraday Discussion of the Chemical Society. 1974. No.58. P.194.

[17] V.P. Grankin. Photoabsorption and photodesorption of hydrogen on the surface of sulfides. Technical Physics Letters. 1994. Vol.20. No.14. P.27-31. (russian)

[18] V.P. Grankin, V.Yu. Shalamov. Photostimulated adsorption and recombination of atomic hydrogen and oxygen on the surface of ZnS,CdS. Bulletin of the Perm State Technical University. 1998. No.6. P.353357. (russian)

[19] E.F. Lazneva, I.N. Alexandrov, L.I. Sergeeva. Desorption of atoms and molecules from the surface of cadmium selenide under the influence of illumination. Izv. USSR Academy of Sciences, ser. physical 1982. Vol.46. P.2248-2251. (russian)

[20] T.T. Bykova, E.F. Lazneva. Change in adsorption equilibrium on the surface of cadmium sulfide under the influence of a light pulse. Semiconductors. 1971. Vol.5. P.774-776. (russian)

[21] T.T. Bykova, E.F. Lazneva. Photoactivated desorption of oxygen from the surface of cadmium sulfide and selenide. Izv. USSR Academy of Sciences. 1979. Vol.43. P.474-477. (russian)

[22] V.F. Markov, L.N. Maskaeva and Ju.S. Polikarpova. Films of supersaturated solid solutions of $\mathrm{cd}_{\mathrm{x}} \mathrm{pb}_{1-}$ xS chemically deposited on porous glass, their structure and properties. Butlerov Communications. 2006. Vol.8. No.1. P.54-61. ROI: jbc-02/6-8-1-54

[23] V.F. Markov, L.N. Maskaeva, Yu.S. Polikarpova. M.P. Mironov, V.N. Rodin, L.S. Soloviev, B.V. Berg, V.N. Potapov. Semiconductor material for a selective detector of nitrogen oxides and method for its preparation. Russian patent No. 2305830, publ. 09/10/2007. (russian)

[24] L.N. Maskaeva, A.D. Kutyavina, V.F. Markov, R.E. Yagovitin, and I.V. Vaganova. Chemical bath synthesis of metal chalcogenide films. Part 32. Influence of the particle size forming polycrital $\mathrm{Cd}_{x} \mathrm{~Pb}_{1-x} \mathrm{~S}$ films on the composition. Butlerov Communications. 2017. Vol.50. No.6. P.86-94. DOI: 10.37952/ROI-jbc-01/20-62-6-1

[25] E.N. Maximova, V.F. Markov, A.E. Bezdetnova, Yu.G. Shashmurin, L.N. Maskaeva, and V.F. Dyakov. Using of chemical sensors for rapid diagnostic tests of exhaled air. Butlerov Communications. 2019. Vol.60. No.12. P.25-36. DOI: 10.37952/ROI-jbc-01/19-60-12-25

[26] V.F. Markov, L.N. Maskaeva, G.A. Kitaev. Prediction of the composition of solid substitutional solutions of $\mathrm{Cd}_{x} \mathrm{~Pb}_{1-x} \mathrm{~S}$ during chemical deposition from aqueous solutions. Inorganic materials. 2000. Vol.36. No.12. P.1421-1423. (russian)

[27] L.N. Maskaeva, P.S. Bogatova, V.F. Markov, A.D. Kutyavina, and Yu.A. Babchenko. Chemical bath synthesis of metal chalcogenide films. Part 41. Effect of $\mathrm{Sr}^{2+}$ ions on deposition kinetics, composition and morphology of $\mathrm{PbS}$ thin films. Butlerov Communications. 2019. Vol.58. No.5. P.141-148. DOI: 10.37952/ROI-jbc-01/19-58-5-141

[28] Марков В.Ф., Маскаева Л.Н., Порхачев М.Ю., Мокроусова О.А. Термическая и радиационная устойчивость ИК-детекторов на основе пленок твердых растворов $\mathrm{Cd}_{x} \mathrm{~Pb}_{1-x} \mathrm{~S}$. Пожаровзрывобезопасность. 2015. Т.24. №9. С.67-73. 